\title{
CONTINUOUS-FLOW AZIDE-ALKYNE CYCLOADDITIONS WITH AN EFFECTIVE BIMETALLIC CATALYST AND A SIMPLE SCAVENGER SYSTEM
}

Sándor B. Ötvös ${ }^{\mathrm{a}}$, Gábor Hatoss ${ }^{\mathrm{a}}$, Ádám Georgiádes ${ }^{\mathrm{a}}$, Szabolcs Kovács ${ }^{\mathrm{b}}$, István M. Mándity ${ }^{\mathrm{a}}$, Zoltán Novák ${ }^{\mathrm{b}}$ and Ferenc Fülöp*a

${ }^{a}$ Institute of Pharmaceutical Chemistry, University of Szeged, Eötvös u. 6, 6720 Szeged, Hungary

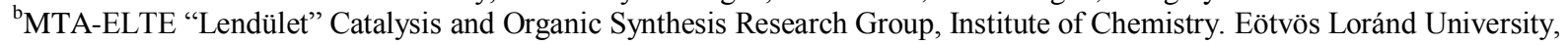
Pázmány Péter stny. 1/a, Budapest, 1117, Hungary

*Corresponding author, email: fulop@ pharm.u-szeged.hu

\begin{abstract}
A flow chemistry-based technique is presented herein for $\mathrm{Cu}(\mathrm{I})$-catalyzed azide-alkyne cycloadditions with a copper on iron bimetallic system as the catalyst and iron powder as a readily available copper-scavenger. The method proved to be rapid and safe as compared with the conventional batch experiment; and by using an in-line copper scavenger, the level of copper impurities in the triazole products could readily be reduced to negligibly small amounts. The process was widely applicable, as not only terminal alkynes, but also various disubstituted acetylenes were nicely tolerated as dipolarophiles leading to useful 1,4,5trisubstituted 1,2,3-triazoles.
\end{abstract}

\section{Introduction}

The 1,3-dipolar cycloaddition of organic azides with alkynes as dipolarophiles is the most straightforward way to obtain useful 1,2,3-triazoles. ${ }^{1}$ The classical Huisgen reaction utilizes only thermal induction and gives an approximately 1:1 mixture of 1,4- and 1,5-disubstituted 1,2,3-triazoles, ${ }^{2}$ but with a $\mathrm{Cu}(\mathrm{I})$ catalysis the 1,4-disubstituted isomer is formed regioselectively. ${ }^{3}$ Applications of the $\mathrm{Cu}(\mathrm{I})$-catalyzed azide-alkyne cycloaddition (CuAAC) have contributed to many areas of modern chemistry, such as bioconjugation, peptidomimetic chemistry, polymer and materials sciences and supramolecular chemistry. ${ }^{4}$ As a consequence of the potential biological properties of 1,2,3-triazole-containing compounds, the CuAAC reaction has recently become a versatile tool for the drug discovery. ${ }^{5}$

As a novel sustainable alternative for conventional batch-based synthetic techniques, continuous-flow (CF) processing has recently emerged in academic and industrial research of fine chemicals. ${ }^{6}$ CF-based approaches offer significant advantages over classical segmented unit operations, ${ }^{7}$ such as enhanced heat and mass transfer and improved mixing properties, ${ }^{8}$ increased parameter space with an unprecedented level of control over the most important reaction conditions, ${ }^{9}$ and inherently safer and greener chemistry and higher reaction rates. ${ }^{10}$ 
The synthesis of 1,2,3-triazoles via CuAAC comprises an extraordinarily robust and straightforward transformation, which can be performed under a wide array of reaction conditions. ${ }^{11}$ For such reactions, the safety aspects associated with the handling of explosive azides, ${ }^{12}$ the inherent scalability of continuous processing and the plausible opportunity for automation have made $\mathrm{CF}$ CuAAC approaches particularly appealing. ${ }^{13}$ In $\mathrm{CF}$ reaction technology, mainly heterogeneous approaches, such as copper-in-charcoal $(\mathrm{Cu} / \mathrm{C}),{ }^{14}$ immobilized $\mathrm{Cu}(\mathrm{I})$ complexes, ${ }^{15}$ copper powder ${ }^{16}$ or heated copper tubing ${ }^{17}$ are employed as sources of catalytically active copper species. Despite using a heterogeneous catalyst, metal impurities often reduce the organic purity of the triazole product due to significant leaching of copper from the catalytic source. ${ }^{14 \mathrm{~b}}$ Flow chemistry enables various in-line techniques (such as the use of metal scavenger resins or CF extraction processes) to reduce copper contamination and to obtain sufficiently purer products with less purification and work-up steps. $^{15 b, 18}$

Herein, we report an effective $\mathrm{CF}$ technique for $\mathrm{CuAAC}$ reactions employing the combination of a copper on iron $(\mathrm{Cu} / \mathrm{Fe})$ bimetallic catalytic system and iron powder as a readily available copper-scavenging unit, which can practically act as an in situ generated catalyst after several hours of continuous operation as a scavenger. The synthetic capabilities of the CF process were validated with the synthesis of a series of 1,4-disubstituted and 1,4,5trisubstituted 1,2,3-triazoles.

\section{Experimental}

\section{CF methodology}

Experiments were conducted in a CF reactor system shown in Fig. 1. A stainless steel cartridge (with internal dimensions of $70 \times 4 \mathrm{~mm}$ ) was employed as the catalyst bed, which was placed in a heating unit or an ultrasonic bath (with a power of $150 \mathrm{~W}$ ). The catalyst bed was combined with a coiled stainless steel line (with an internal diameter of $500 \mu \mathrm{m}$ ) for preheating of the liquid phase before entering the column. A backpressure regulator ensured constant pressures up to a maximum of $100 \mathrm{bar}$, and the mixture of the reactants was pumped through the system continuously by means of a conventional HPLC pump. For reactions with in line copper scavenging, a second cartridge (with the same dimensions) was filled with scavenger and fitted into the flow line. 


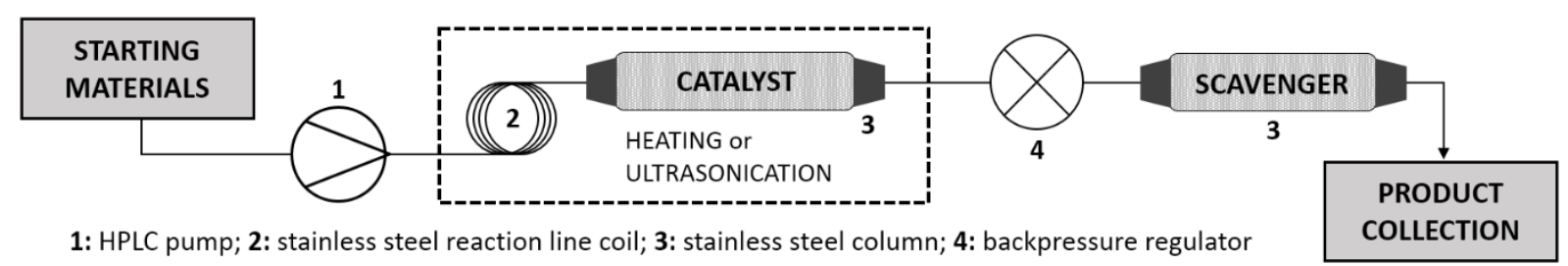

Fig. 1. Experimental setup for the CF reactions.

\section{Materials}

Copper powder (average particle size: $200 \mu \mathrm{m}$ ) and 5 wt. \% $\mathrm{Cu} / \mathrm{C}$ (average particle size: 20 $\mu \mathrm{m})$ were purchased from Aldrich, and used as received. 5 wt. \% $\mathrm{Cu} / \mathrm{Fe}$ (average particle size: $200 \mu \mathrm{m}$ ) was prepared from $\mathrm{CuSO}_{4}$ and iron powder as reducing agent, according to the previously described procedure. ${ }^{19}$ Iron powder (used as scavenger) was purchased from Alfa Aesar with an average particle size of $200 \mu \mathrm{m}$. Azides, as starting materials were prepared with literature procedures in purities of $>99 \%$, and were therefore used without further purification. $^{16 \mathrm{a}, 19 \mathrm{~b}, 20}$

\section{General procedure}

In the case of copper powder and $\mathrm{Cu} / \mathrm{Fe}, 1 \mathrm{~g}$ of the heterogeneous catalyst was filled into a catalyst bed, respectively. Due to the large porosity of activated charcoal, it was possible to load only $0.5 \mathrm{~g}$ of $\mathrm{Cu} / \mathrm{C}$ into the cartridge at a maximum. The scavenger column was loaded with $1 \mathrm{~g}$ of iron powder.

For the small-scale CF reactions, $0.84 \mathrm{mmol}$ (1 equiv.) of the azide and $1.26 \mathrm{mmol}$ (1.5 equiv.) of the alkyne were dissolved in $10 \mathrm{~mL} \mathrm{CH}_{2} \mathrm{Cl}_{2}$. If necessary, $0.0336 \mathrm{mmol}$ (0.04 equiv.) of $\mathrm{N}, \mathrm{N}$-diisopropylethylamine (DIEA) and $0.0336 \mathrm{mmol}$ (0.04 equiv.) of glacial acetic acid $(\mathrm{AcOH})$ were added as additives. After homogenization, the solution was pumped through the $\mathrm{CF}$ reactor under the appropriate conditions. Between two $\mathrm{CF}$ reactions the catalyst bed and the scavenger were washed at room temperature (RT) for $10 \mathrm{~min}$ with $\mathrm{CH}_{2} \mathrm{Cl}_{2}$ at a flow rate of $1 \mathrm{~mL} \min ^{-1}$. The concentration of the reactants was not varied upon scaling-up, and a larger amount of starting medium was simply pumped through the instrument. The crude products were checked by thin-layer chromatography with a mixture of $n$-hexane/EtOAc as eluent, and the solvent was next evaporated off under vacuum. If necessary, column chromatographic purification was carried out on silica gel with a mixture of $n$-hexane/EtOAc as eluent.

To determine the residence time on the filled catalyst bed, a solution of a dye was pumped through the cartridge. The time that elapsed between the first contact of the dye with 
the catalyst bed and the moment when the colored solution appeared at the column output was measured.

\section{Product analysis}

The obtained 1,2,3-triazoles were characterized by NMR experiments and elemental analyses. ${ }^{1} \mathrm{H}$ and ${ }^{13} \mathrm{C}$ NMR spectra were recorded on a Bruker Avance DRX 400 spectrometer, in $\mathrm{CDCl}_{3}$ as solvent, with TMS as internal standard, at 400.1 and $100.6 \mathrm{MHz}$, respectively. Microanalyses were performed on a Perkin-Elmer 2400 elemental analyzer.

The copper concentration of the samples was determined by inductively coupled plasma mass spectrometer (ICP-MS), using an Agilent 7700x-type instrument equipped with a collision cell after digestion with concentrated $\mathrm{HNO}_{3}$. The determination was carried out on the isotope ${ }^{63} \mathrm{Cu}$, with $\mathrm{He}$ as collision gas.

The morphology of the catalyst and the scavenger was examined with scanning electron microscopy (SEM - Hitachi S-4700 microscope with varying acceleration voltage). The samples were fixed on a double-sided adhesive carbon tape and were coated with gold using a sputter coater (Quorum Technologies SC7620). The approximate composition and the elemental map of the substances were investigated by a Röntec QX2 energy dispersive X-ray fluorescence spectrometer (EDX) coupled to the microscope.

\section{Results and discussion}

$\mathrm{Cu} / \mathrm{Fe}$ is a versatile bimetallic catalyst system which consists of nano-sized copper particles deposited onto an iron surface (Fig. 2). ${ }^{19,21}$ It can easily be prepared from $\mathrm{Cu}$ (II) salts and iron powder which serves as a non-toxic reducing agent and a support for copper particles at the same time. As the beginning of our study, we explored the merits of the $\mathrm{Cu} / \mathrm{Fe}$ system for $\mathrm{CuAAC}$ reactions in a high-pressure $\mathrm{CF}$ device in comparison with $\mathrm{Cu} / \mathrm{C}$ and copper powder as commercially available $\mathrm{Cu}(\mathrm{I})$ sources and also with literature batch data employing the same catalyst (Table 1). The 1,3-dipolar cycloaddition between benzyl azide and phenylacetylene was chosen as a test reaction with $\mathrm{CH}_{2} \mathrm{Cl}_{2}$ as solvent. A reaction mixture containing 1 equiv. of the azide and 1.5 equiv. of the alkyne was pumped through the reactor in each run. The azide was applied in a concentration of $0.085 \mathrm{M}$, which was the highest possible concentration preventing the precipitation of the resulting product and a blockage in the channels of the reactor. All CF reactions were carried out at a flow rate of $0.5 \mathrm{~mL} \mathrm{~min}{ }^{-1}$ which involved a residence time on the catalyst bed as low as $1.5 \mathrm{~min}$, and thus a prominently short process time. 


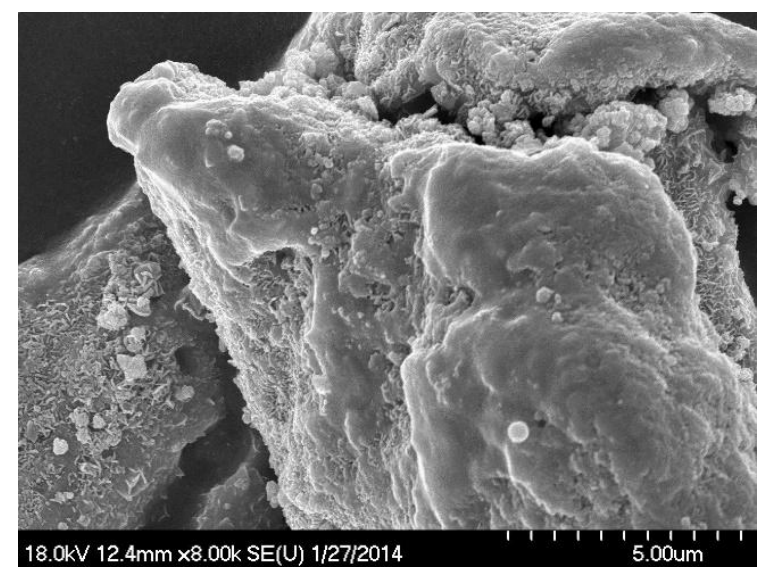

Fig. 2. SEM image of the $\mathrm{Cu} / \mathrm{Fe}$ catalyst.

At ambient temperature and pressure, low conversion was obtained with each catalyst (entries 1, 6 and 11), and thus various approaches were evaluated to improve the reactivity. High pressures can enhance the rate of the triazole formation in accordance with Le Chatelier's principle, and accordingly we found higher conversions at 100 bar (entries 2, 7 and 12). ${ }^{16 a}$ Elevation of the pressure allowed the use of temperatures well above the boiling point of $\mathrm{CH}_{2} \mathrm{Cl}_{2}$, thus, as a next step, high-temperature conditions were examined. At 100 bar and $100^{\circ} \mathrm{C} \mathrm{Cu} / \mathrm{Fe}$ and copper powder performed equally well, as quantitative conversion was achieved in the test reaction with both catalysts (entries 3 and 13). In contrast, with $\mathrm{Cu} / \mathrm{C} \mathrm{a}$ conversion of only $38 \%$ was found (entry 8 ). Due to the risks associated with the handling of explosive azides it is highly beneficial to improve the rates of the $\mathrm{CuAAC}$ reactions without high temperatures. Amines, as basic additives, are known to boost the reactivity of the CuAAC considerably, ${ }^{3 a, 11,22}$ and it was recently shown that the addition of catalytic amounts of certain acids can further accelerate the triazole formation and also prevent the accumulation of unwanted byproducts. ${ }^{23}$ To realize the $\mathrm{CF} \mathrm{CuAAC}$ at ambient temperature, we utilized 0.04 equiv. of DIEA and 0.04 equiv. of $\mathrm{AcOH}$ jointly as additives. ${ }^{16 \mathrm{a}} \mathrm{We}$ were pleased to find that the performance of the $\mathrm{Cu} / \mathrm{Fe}$ catalyst was comparable with copper powder, and quantitative conversion was achieved with additives in both cases (entries 4 and 14). In case of $\mathrm{Cu} / \mathrm{C}$ the use of additives nicely improved the reactivity as compared with the high-temperature/highpressure conditions, and gave an acceptable conversion of $81 \%$ (entry 9). We also checked the effects of ultrasound promotion to relieve harsh reaction conditions. ${ }^{24}$ For this, the filled catalyst column was simply placed into an ultrasonic bath. It was found that sonication improved the rates of the $\mathrm{CF}$ reaction at ambient temperature in case of the bimetallic $\mathrm{Cu} / \mathrm{Fe}$ system and copper powder, but the efficacy of this approach fell behind the use of additives, as a conversion of only $\sim 50 \%$ was obtained with both catalysts (entries 5 and 15). In case of $\mathrm{Cu} / \mathrm{C}$, not more than a negligible conversion increase was found upon sonication (entry 10). 
The overall lower reactivity of $\mathrm{Cu} / \mathrm{C}$ may be explained with the poorer accessibility of the catalytically active $\mathrm{Cu}(\mathrm{I})$ species in the activated charcoal matrix and with the lower catalyst loading in the cartridge than is the case of $\mathrm{Cu} / \mathrm{Fe}$ and copper powder.

Table 1. Effects of different catalysts and reaction conditions on the CF CuAAC.

\begin{tabular}{|c|c|c|c|c|c|c|c|}
\hline \multicolumn{3}{|l|}{$\begin{array}{c}\mathrm{Ph} \mathrm{N}_{3} \\
1 \text { equiv. } \\
c_{\text {azide }}=0.085 \mathrm{M}\end{array}$} & \multicolumn{2}{|c|}{$\begin{array}{c}\mathrm{CH}_{2} \mathrm{Cl}_{2} \\
\text { catalyst, } p, T \\
\text { CF reactor } \\
0.5 \mathrm{~mL} \mathrm{~min}^{-1}\end{array}$} & \multicolumn{2}{|c|}{$\mathrm{Ph}_{1}^{\mathrm{N}=\mathrm{N}}$} & \multirow[b]{2}{*}{$\begin{array}{l}\text { Conversion } \\
\text { of } 1(\%)^{\mathrm{a}}\end{array}$} \\
\hline Entry & \multicolumn{2}{|c|}{ Catalyst } & $p$ (bar) & $T\left({ }^{\circ} \mathrm{C}\right)$ & $\begin{array}{l}\text { Additives } \\
\text { DIEA } \\
\text { (equiv.) }\end{array}$ & $\begin{array}{l}\mathrm{AcOH} \\
\text { (equiv.) }\end{array}$ & \\
\hline 1 & \multicolumn{2}{|c|}{ copper powder } & 1 & RT & 0 & 0 & 19 \\
\hline 2 & \multicolumn{2}{|c|}{ copper powder } & 100 & RT & 0 & 0 & 31 \\
\hline 3 & \multicolumn{2}{|c|}{ copper powder } & 100 & 100 & 0 & 0 & quant. \\
\hline 4 & \multicolumn{2}{|c|}{ copper powder } & 100 & RT & 0.04 & 0.04 & quant. \\
\hline 5 & \multicolumn{2}{|c|}{ copper powder } & 100 & $\mathrm{RT} / \mathrm{US}^{\mathrm{c}}$ & 0 & 0 & 54 \\
\hline 6 & \multicolumn{2}{|l|}{$\mathrm{Cu} / \mathrm{C}$} & 1 & RT & 0 & 0 & 6 \\
\hline 7 & \multicolumn{2}{|l|}{$\mathrm{Cu} / \mathrm{C}$} & 100 & RT & 0 & 0 & 11 \\
\hline 8 & \multicolumn{2}{|l|}{$\mathrm{Cu} / \mathrm{C}$} & 100 & 100 & 0 & 0 & 38 \\
\hline 9 & \multicolumn{2}{|l|}{$\mathrm{Cu} / \mathrm{C}$} & 100 & RT & 0.04 & 0.04 & 81 \\
\hline 10 & \multicolumn{2}{|l|}{$\mathrm{Cu} / \mathrm{C}$} & 100 & RT/US ${ }^{c}$ & 0 & 0 & 15 \\
\hline 11 & \multicolumn{2}{|l|}{$\mathrm{Cu} / \mathrm{Fe}$} & 1 & RT & 0 & 0 & 21 \\
\hline 12 & \multicolumn{2}{|l|}{$\mathrm{Cu} / \mathrm{Fe}$} & 100 & RT & 0 & 0 & 28 \\
\hline 13 & \multicolumn{2}{|l|}{$\mathrm{Cu} / \mathrm{Fe}$} & 100 & 100 & 0 & 0 & quant. $(98)^{\mathrm{d}}$ \\
\hline 14 & \multicolumn{2}{|l|}{$\mathrm{Cu} / \mathrm{Fe}$} & 100 & RT & 0.04 & 0.04 & quant. (99) ${ }^{\mathrm{d}}$ \\
\hline 15 & \multicolumn{2}{|l|}{$\mathrm{Cu} / \mathrm{Fe}$} & 100 & RT/US ${ }^{\mathrm{c}}$ & 0 & 0 & 49 \\
\hline $16^{\mathrm{b}}$ & \multicolumn{2}{|l|}{$\mathrm{Cu} / \mathrm{Fe}$} & 1 & 30 & 0 & 0 & quant. $(98)^{\mathrm{d}}$ \\
\hline
\end{tabular}

${ }^{\mathrm{a}}$ Determined by ${ }^{1} \mathrm{H}$ NMR spectroscopic analysis of the crude material.

${ }^{\mathrm{b}}$ Batch reference data. ${ }^{19 \mathrm{~b}}$ Reaction conditions: azide $(0.5 \mathrm{mmol}, 1$ equiv. $)$, acetylene $(0.5 \mathrm{mmol}, 1 \mathrm{equiv}),. \mathrm{Cu} / \mathrm{Fe}$ (5 mol\%, 5 wt. \%) (32 mg, $0.025 \mathrm{mmol}$ copper), $\mathrm{CH}_{2} \mathrm{Cl}_{2},(300 \mu \mathrm{L})$, stirring at $30{ }^{\circ} \mathrm{C}$ for $8 \mathrm{~h}$.

${ }^{\mathrm{c}}$ US stands for ultra sound.

${ }^{\mathrm{d}}$ Isolated yield.

The $\mathrm{CF}$ results with the $\mathrm{Cu} / \mathrm{Fe}$ catalyst system (obtained either under hightemperature/high-pressure conditions or under ambient temperature with additives) compare well with the corresponding literature batch data utilizing the same catalyst and conventional mechanical stirring at $30^{\circ} \mathrm{C}$ (entries 13,14 vs. 16). ${ }^{19 \mathrm{~b}}$ It should be pointed out that the batch reaction required $8 \mathrm{~h}$ of reaction time for completion, whereas the continuous process offered quantitative conversion in a short residence time on the catalyst bed, and thus it proved to be 
much more rapid. Another point is that the CF method tends to be safer due to the contained environment, the lack of headspace and the well-defined short residence time.

In reactions involving heterogeneous catalysts, leaching of copper from the catalyst bed can reduce the purity of the triazole products and necessitate further work-up and purification steps. In our CF reactions, trace amounts of copper were determined by means of ICP-MS measurements in the quantitatively obtained triazole products without any work-up and purification steps other than a simple evaporation. The analytical data in Table 2 show that the copper content of the crude products obtained under high-pressure/high-temperature conditions without any additives were lower than those when DIEA and $\mathrm{AcOH}$ were jointly applied (entries 1 vs. 2). This is because amines, as basic additives, can coordinate to the catalytically active $\mathrm{Cu}(\mathrm{I})$ species and promote their liberation from the copper matrix, thereby increasing the copper content of the crude product. In spite of this fact, the utilization of additives for rate enhancement in the $\mathrm{CF} \mathrm{CuAAC}$ is much wiser than the use of harsh reaction conditions due to safety considerations. Thus, to reduce metal contamination of the triazole product an in-line copper scavenging methodology is highly beneficial.

Table 2. Copper contents in the triazole product obtained with different approaches.

\begin{tabular}{|c|c|c|c|c|}
\hline $\begin{array}{c}\mathrm{Ph}^{\prime} \\
1 \mathrm{e} \\
c_{\text {azide }}=\end{array}$ & $\begin{array}{l}\mathrm{N}_{3} \\
\text { div. } \\
085 \mathrm{M}\end{array}$ & $\begin{array}{l}\mathrm{Ph}= \\
1.5 \text { equiv. }\end{array}$ & $\underset{0.5 \mathrm{~mL} \mathrm{~min}-1}{\stackrel{\mathrm{CH}_{2} \mathrm{Cl}_{2}}{\text { catalyst, } p, T}} \rightarrow{ }_{1}$ & \\
\hline Entry & \multicolumn{3}{|c|}{ Description of the reaction conditions } & Copper content $\left(\mu \mathrm{g} \mathrm{g}^{-1}\right)^{\mathrm{a}}$ \\
\hline 1. & \multicolumn{3}{|c|}{$\mathrm{Cu} / \mathrm{Fe}, 100$ bar, $100^{\circ} \mathrm{C}$, without additives } & $41.0 \pm 0.8$ \\
\hline 2. & \multicolumn{3}{|c|}{$\mathrm{Cu} / \mathrm{Fe}, 100$ bar, $\mathrm{RT}$, with additives ${ }^{\mathrm{b}}$} & $318.3 \pm 2.9$ \\
\hline 3. & \multicolumn{3}{|c|}{$\mathrm{Cu} / \mathrm{Fe}, 100$ bar, $\mathrm{RT}$, with additives, ${ }^{\mathrm{b}}$ purification on a flash column } & $7.8 \pm 0.3$ \\
\hline 4. & \multicolumn{3}{|c|}{$\mathrm{Cu} / \mathrm{Fe}, 100$ bar, $\mathrm{RT}$, with additives ${ }^{\mathrm{b}}$, in line purification with scavenger } & $19.4 \pm 0.6$ \\
\hline
\end{tabular}

${ }^{\mathrm{a}}$ Determined by ICP-MS

${ }^{\mathrm{b}}$ Additives: 0.04 equiv. DIEA +0.04 equiv. AcOH.

The development of the $\mathrm{Cu} / \mathrm{Fe}$ bimetallic catalyst system inspired us to employ iron powder in our CF system as a readily available copper scavenger. Thus, iron powder was filled in a second cartridge which was placed into the flow line according to Fig. 1. We were pleased to find that the utilization of iron powder as scavenger dramatically reduced the copper content of the triazole product (entries 2 vs. 4), it proved nearly as effective as a conventional off line purification with column chromatography (entries 3 vs. 4). With in-line copper scavenging, the corresponding 1,4-disubstituted 1,2,3-triazole product was achieved without work-up and purification steps as conversion was quantitative and any excess alkyne could evaporated. 
We next investigated the large-scale synthetic capabilities of the $\mathrm{Cu} / \mathrm{Fe}+\mathrm{Fe}$ catalyst and scavenger system with the test reaction between benzyl azide and phenylacetylene at a flow rate of $0.5 \mathrm{~mL} \mathrm{~min}{ }^{-1}$, a pressure of $100 \mathrm{bar}$, and at ambient temperature with the joint use of DIEA and $\mathrm{AcOH}$ as additives. The concentration and ratio of the starting materials were not changed upon scaling-up. Fractions of the reaction product were collected every 15 minutes, and conversion was determined for each portion. We were pleased to find that the activity of the catalyst remained constant after $150 \mathrm{~min}$ of continuous use, and $1.38 \mathrm{~g}$ of triazole 1 was obtained without the need for further work-up or purification steps (Table 3). In this experiment, an overall yield of $94 \%$ and a productivity of 3 (in mmol product $\times$ mmol catalyst $^{-1} \times \mathrm{h}^{-1}$ ) was achieved. We presumed that the iron powder used as scavenger in the large-scale experiment may have catalytic activity in $\mathrm{CuAAC}$ reactions due to various copper species adsorbed on its surface. Thus the cartridge containing iron powder after $150 \mathrm{~min}$ of continuous copper scavenging was recycled as an in line-generated catalyst column (marked as ' $\mathrm{Cu}$ '/Fe from here on) in a large-scale run utilizing the same reactants and conditions as in the previous experiment (Table 4). It was found that ' $\mathrm{Cu}$ '/Fe effectively catalyzed the $\mathrm{CF}$ CuAAC reaction with constant activity in the first $100 \mathrm{~min}$. After that, the activity started to decrease, and in the final fraction a conversion of $31 \%$ was obtained. The experiment allowed for the isolation of $1.10 \mathrm{~g}$ of pure triazole 1 with a good overall yield of $75 \%$. The SEM images of the iron powder nicely supported the above findings. As shown in Fig. 3a, the surface of the unused iron powder is smooth, but after $150 \mathrm{~min}$ of continuous use as a scavenger, small particles appeared on it (Fig. 3b), and the morphology of the surface became similar to that of the $\mathrm{Cu} / \mathrm{Fe}$ catalyst (Fig. $3 \mathrm{~b}$ vs. Fig. 2). The EDX measurements verified our suspicion that the small dots on the surface of ' $\mathrm{C} u$ '/Fe are copper nanoparticles, which allowed for catalytic activity in the $\mathrm{CuAAC}$ reaction. Thus, the above sustainable procedure allows not only for CF triazole formation with in line copper scavenging but, at the same time, its efficacy for continuous catalyst generation is also noted. 
Table 3. Investigation of the large-scale synthetic capabilities of the $\mathrm{Cu} / \mathrm{Fe}+\mathrm{Fe}$ catalytic system in $\mathrm{CF}$.

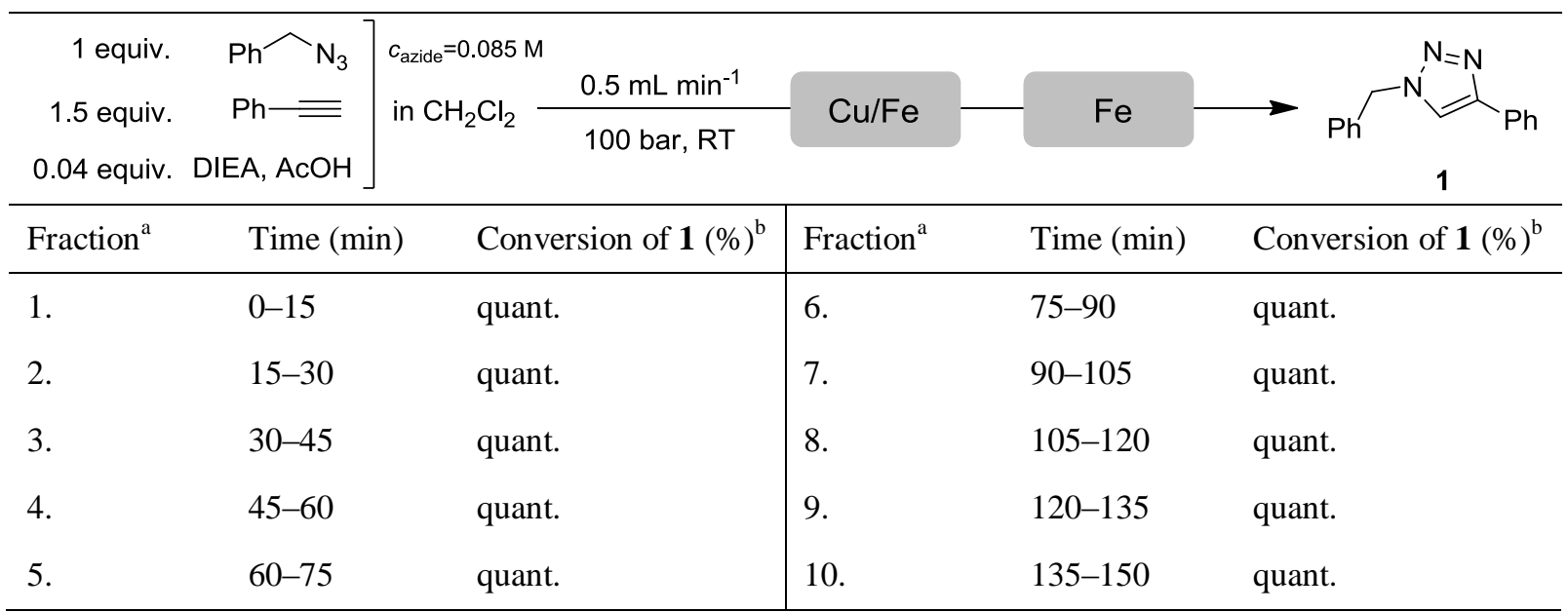

${ }^{\mathrm{a}} 1.38 \mathrm{~g}$ of 1 was collected in the whole experiment. An overall yield of $94 \%$ and a productivity of 3 (in mmol product $\times$ mmol catalyst ${ }^{-1} \times \mathrm{h}^{-1}$ ) was obtained.

${ }^{b}$ Determined by ${ }^{1} \mathrm{H}$ NMR spectroscopic analysis of the crude material.

Table 4. Investigation of the catalytic capabilities of the same portion of iron powder previously used as copperscavenging unit in the experiment shown in Table 3.

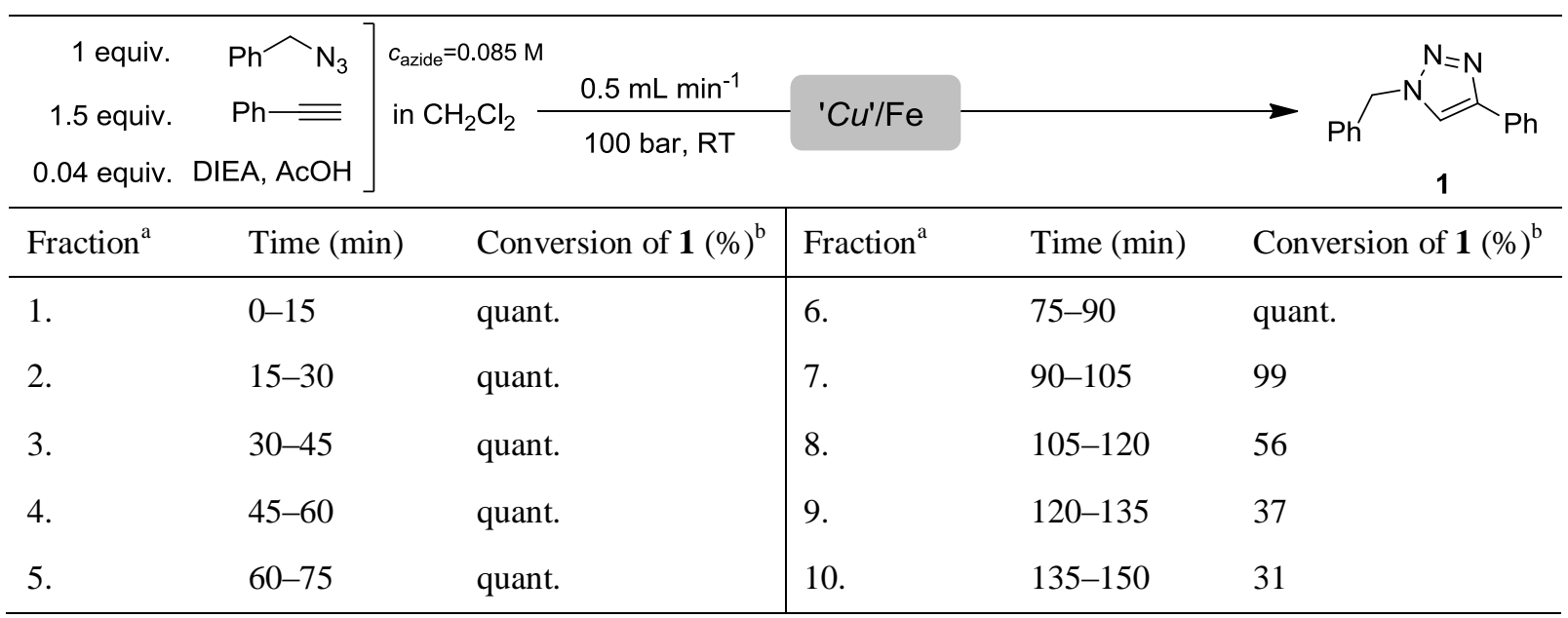

${ }^{\mathrm{a}} 1.10 \mathrm{~g}$ of $\mathbf{1}$ was collected in the whole experiment. An overall yield of $75 \%$ was obtained.

${ }^{\mathrm{b}}$ Determined by ${ }^{1} \mathrm{H}$ NMR spectroscopic analysis of the crude material.

(a)
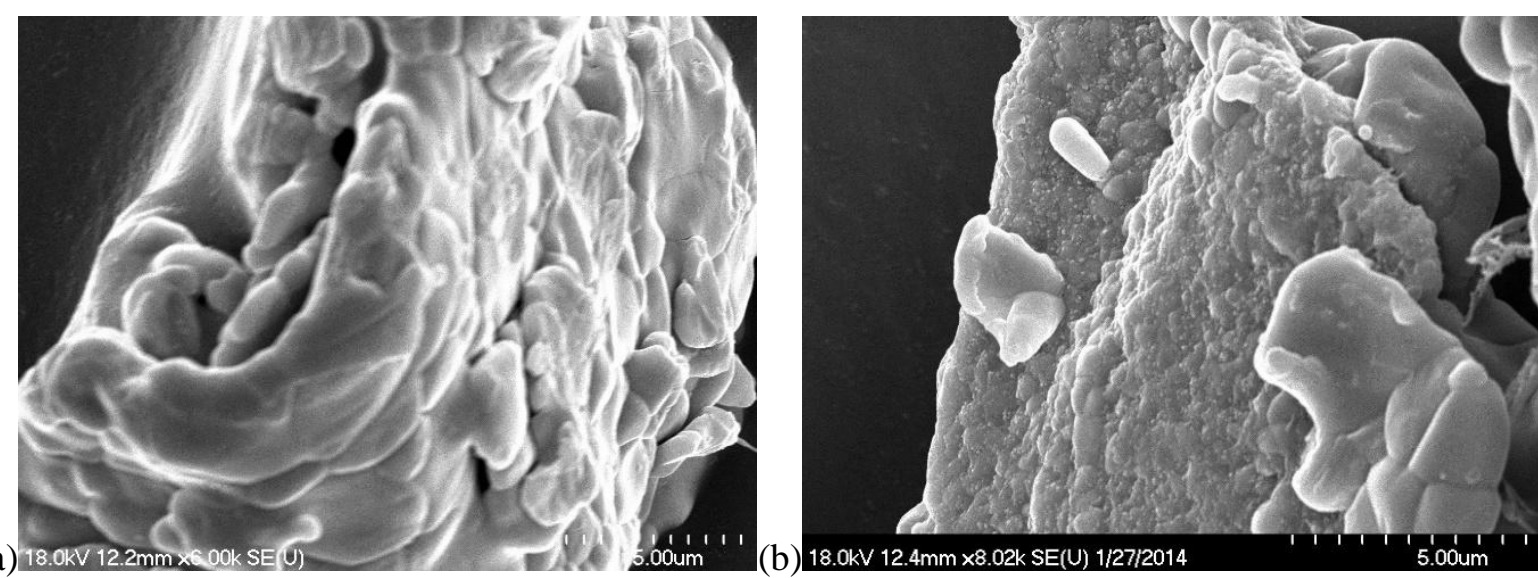

Fig. 3. SEM images of the iron powder: (b) unused iron powder; (c) used iron powder, sample taken after 150 min of CF operation as scavenger (see Table 3 ). 
To investigate the applicability of the $\mathrm{CF}$ method, a wide array of $\mathrm{CuAAC}$ reactions were carried out utilizing the $\mathrm{Cu} / \mathrm{Fe}$ catalytic system at a flow rate of $0.5 \mathrm{~mL} \mathrm{~min}^{-1}$, a pressure of 100 bar, with the joint use of DIEA and $\mathrm{AcOH}$ as additives at ambient temperature. At first, the azide scope was examined, employing phenylacetylene as dipolarophile. As can be seen in Table 5, excellent results were achieved with either aliphatic or aromatic azides. In the case of aromatic azides, it was found that either electron-withdrawing (entries 2-4) or electron-donating substituents (entries 5 and 6) are nicely tolerated on the aromatic ring. High conversions and yields were achieved with cyclic, linear, branched and unsaturated nonaromatic azides as well (entries 7-12). Reactions of a series of alkynes with benzyl azide were also carried out. It was found that, besides phenylacetylene, non-aromatic alkynes, such as pent-1-yne, ethyl propiolate and propargyl acetate, are nicely tolerated (entries 13-16). Ferrocene-triazole conjugates are widely applied in medicinal chemistry for the labeling and detection of various systems. ${ }^{25}$ Thus, CuAAC of benzyl azide with ethynyl ferrocene was also attempted, and ferrocene-substituted triazole 18 was obtained in an excellent yield of 90\% (entry 18). In the above experiments the corresponding 1,4-disubstituted 1,2,3-triazole isomers were formed regioselectively, and formation of the 1,5-disubsituted products was not observed. No work-up or purification steps were necessary when the triazole formation was quantitative and any excess alkyne could be volatilized on evaporation (entries 1-6 and 8-12).

Cycloaddition of disubstituted acetylenes with azides leads to synthetically useful 1,4,5-trisubstituted 1,2,3-triazoles, however the scope of this transformation is mostly limited to 1 -haloalkynes. ${ }^{26}$ Other internal acetylenes have only rarely been used as dipolarophiles in CuAAC reactions, ${ }^{27}$ mainly due to the fact that the activation toward cycloaddition via coordination of $\mathrm{Cu}(\mathrm{I})$ to the alkyne without the possibility of deprotonation involves a significantly higher energetic barrier than is the case with terminal alkynes. ${ }^{28}$ However, the high activity of the $\mathrm{Cu} / \mathrm{Fe}$ catalyst system in $\mathrm{CuAAC}$ prompted us to test its reactivity with internal alkynes as well. Reactions of benzyl azide with various disubstituted acetylenes were thus explored. We found that in case of electron-deficient alkynes the use of the CF system with the $\mathrm{Cu} / \mathrm{Fe}$ catalyst (further conditions are as follows: a flow rate of $0.5 \mathrm{~mL} \mathrm{~min}^{-1}$, a pressure of 100 bar, with 0.04 equiv. DIEA +0.04 equiv. $\mathrm{AcOH}$ at ambient temperature) allowed for the desired trisubstituted triazoles. For example, triazole 19, which is itself a potent antitubercular agent, ${ }^{29}$ could be obtained from diethyl acetylenedicarboxylate and benzyl azide in quant. conversion and with a yield of $90 \%$ (entry 19). Conversion decreased significantly when more electron rich alkynes, such as 1,4-dichlorobut-2-yne and 1-iodo-2(trimethylsilyl)acetylene, were reacted (entries 20 and 21). Formation of trisubstituted 
triazoles was not observed from internal alkynes decorated with two electron donating substituents, such as oct-4-yne and diphenylacetylene. This suggests that the electron density of the triple bond is a crucial factor in the reactions of disubstituted acetylenes.

Table 5. Investigation of the scope of the $\mathrm{CF} \mathrm{CuAAC}$ methodology with the $\mathrm{Cu} / \mathrm{Fe}$ catalyst system. ${ }^{\mathrm{a}}$

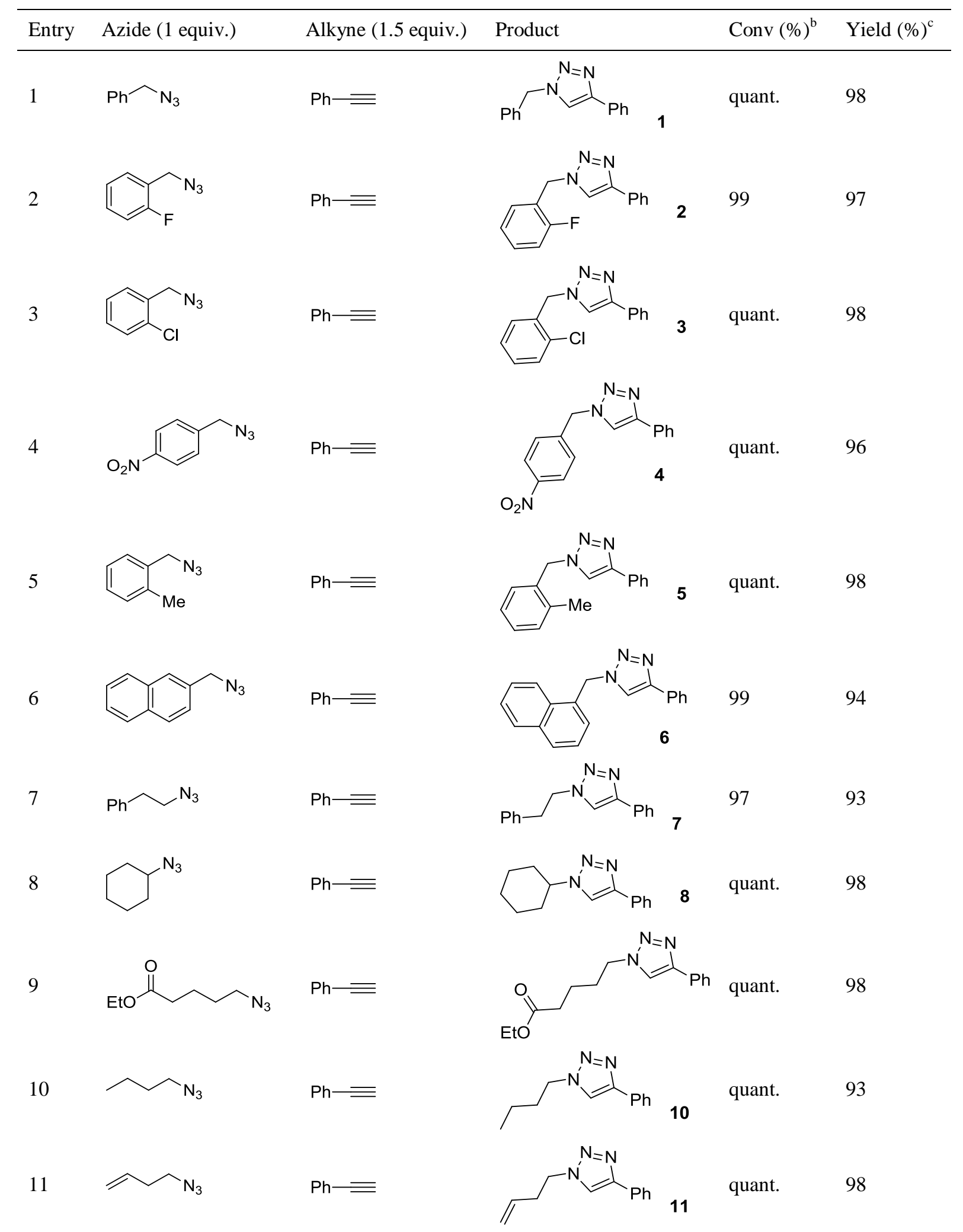


12<smiles>CC(C[N])CCl</smiles>

$\mathrm{Ph}=$

13

$\mathrm{Ph} \widehat{\mathrm{N}_{3}}$

14

$\mathrm{Ph} \widehat{\mathrm{N}_{3}}$

15

$\mathrm{Ph} \widehat{\mathrm{N}_{3}}$

16

$\mathrm{Ph} \widehat{\mathrm{N}_{3}}$

17

$\mathrm{Ph} \mathrm{N}_{3}$

18

$\mathrm{Ph} \mathrm{N}_{3}$

19

$$
\mathrm{Ph} \widehat{\mathrm{N}_{3}}
$$

20<smiles>[N]Cc1ccccc1</smiles>

21<smiles>C#CCCC</smiles><smiles>C#CC(=O)OCC</smiles><smiles>C#CCOC(C)=O</smiles><smiles>C#CCCCC#N</smiles><smiles>C#CCNC(=O)c1ccccc1</smiles>
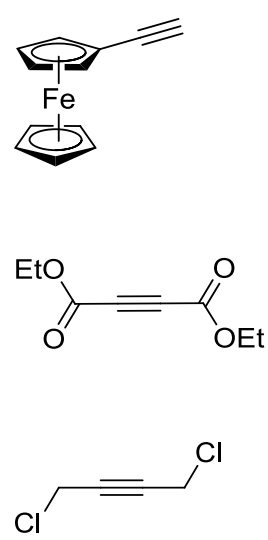

$\mathrm{I}=\mathrm{TMS}$<smiles>CC(CCl)Cn1cc(P)nn1</smiles>

quant.<smiles>CCCc1cn(Cc2ccccc2)nn1</smiles>

90
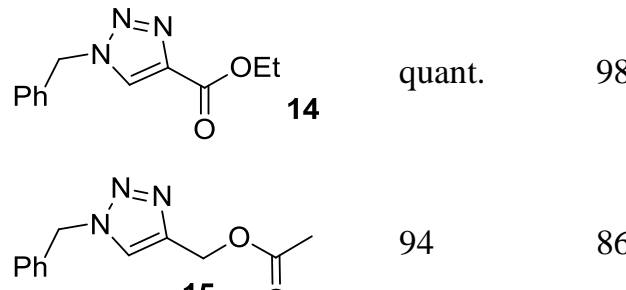<smiles>CCCCC[134I]</smiles>

86

16

98<smiles>N#CCCCC1=CN(Cc2ccccc2)CC1</smiles>
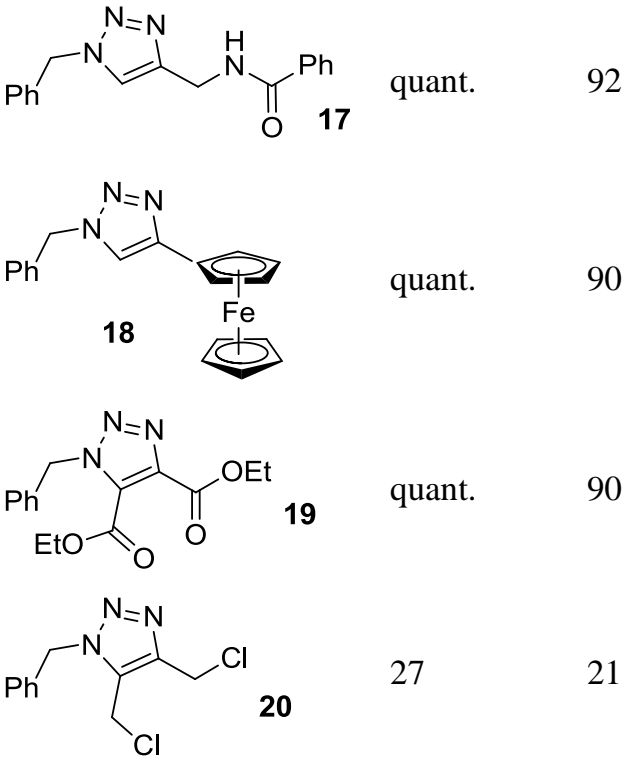<smiles>CS(=O)(=O)c1nnn(Cc2ccccc2)c1I</smiles>

${ }^{\mathrm{a}}$ Conditions: $c_{\text {azide }}=0.085 \mathrm{M}, 100 \mathrm{bar}, \mathrm{RT}, 0.5 \mathrm{~mL} \mathrm{~min}^{-1}$ flow rate, with 0.04 equiv. DIEA +0.04 equiv. AcOH.

${ }^{\mathrm{b}}$ Determined by ${ }^{1} \mathrm{H}$ NMR spectroscopic analysis of the crude material.

${ }^{c}$ Yield of isolated product.

\section{Conclusions}

The efficacy of $\mathrm{Cu} / \mathrm{Fe}$ bimetallic catalyst system for $\mathrm{CuAAC}$ reactions was evaluated in a continuously operating system. It was found that $\mathrm{Cu} / \mathrm{Fe}$ acts as an outstandingly active and robust catalyst. Due to the high flow rate and short process time utilized for the cycloaddition, the $\mathrm{CF}$ technique proved much more rapid than the corresponding batch method. As an additional advantage, the continuous operation provided a contained environment free from 
harsh reaction conditions to minimize the hazards associated with the handling of explosive azides. It was shown that a column filled with simple iron powder can act as a readily available copper scavenging unit and decrease the copper contaminations of the triazole products significantly. With the opportunity of in-line copper scavenging, the level of copper concentrations can readily be reduced to negligibly small amounts and synthetically useful 1,2,3-triazoles can be obtained in a simple and easy manner without any purification or workup steps. After several hours of continuous use as scavenger, the iron powder can be reused as an in situ formed catalyst for $\mathrm{CuAAC}$ reactions thereby extending the synthetic capabilities of the methodology. The scope and applicability of the CF process was found extremely wide for different azides and alkynes. Not only terminal alkynes, but electron deficient disubstituted acetylenes were also tolerated as dipolarophiles, leading to synthetically useful 1,4,5trisubstituted 1,2,3-triazoles.

\section{Acknowledgements}

We are grateful to the Hungarian Research Foundation (OTKA NK81371 and PD103994). and TÁMOP-4.2.2/A-11/1/KONV-2012-0035 for financial support. S. B. Ötvös acknowledges TÁMOP 4.2.4.A/2-11-1-2012-0001 'National Excellence Program', the project was supported by the European Union and the State of Hungary, co-financed by the European Social Fund. I.M.M. acknowledges the award of a János Bolyai scholarship from the Hungarian Academy of Sciences. Z.N acknowledges for the generous support of "Lendület" Research Scholarship Fund of the Hungarian Academy of Sciences (LP2012-48/2012), and OTKA-NKTH (CK80763). The authors also thank Prof. Tim Peelen (Lebanon Valley College) for the proofreading of this manuscript.

\section{References}

1. C.-K. Sha and A. K. Mohanakrishnan, in Synthetic Applications of 1,3-Dipolar Cycloaddition Chemistry Toward Heterocycles and Natural Products, John Wiley \& Sons, 2003, pp. 623-679.

2. R. Huisgen, Angew. Chem. Int. Ed., 1963, 2, 565.

3. (a) V. V. Rostovtsev, L. G. Green, V. V. Fokin and K. B. Sharpless, Angew. Chem. Int. Ed., 2002, 41, 2596; (b) C. W. Tornøe, C. Christensen and M. Meldal, J. Org. Chem., 2002, 67, 3057.

4. (a) K. Kempe, A. Krieg, C. R. Becer and U. S. Schubert, Chem. Soc. Rev., 2012, 41, 176; (b) X. Li, Chem. Asian J., 2011, 6, 2606; (c) D. S. Pedersen and A. Abell, Eur. J. Org. Chem., 2011, 2399; (d) Y. Hua and A. H. Flood, Chem. Soc. Rev., 2010, 39, 1262.

5. (a) S. G. Agalave, S. R. Maujan and V. S. Pore, Chem. Asian J., 2011, 6, 2696; (b) A. D. Moorhouse and J. E. Moses, ChemMedChem, 2008, 3, 715.

6. T. Wirth, Microreactors in Organic Chemistry and Catalysis, John Wiley \& Sons, 2013.

7. (a) C. Wiles and P. Watts, Green Chem., 2014, 16, 55; (b) D. T. McQuade and P. H. Seeberger, J. Org. Chem., 2013, 78, 6384; (c) C. Wiles and P. Watts, Green Chem., 2012, 14, 38; (d) J. 
Wegner, S. Ceylan and A. Kirschning, Adv. Synth. Catal., 2012, 354, 17; (e) J. Wegner, S. Ceylan and A. Kirschning, Chem. Commun., 2011, 47, 4583.

8. R. L. Hartman, J. P. McMullen and K. F. Jensen, Angew. Chem. Int. Ed., 2011, 50, 7502.

9. (a) V. Hessel, D. Kralisch, N. Kockmann, T. Noël and Q. Wang, ChemSusChem, 2013, 6, 746; (b) J.-i. Yoshida, Y. Takahashi and A. Nagaki, Chem. Commun., 2013, 49, 9896.

10. (a) S. G. Newman and K. F. Jensen, Green Chem., 2013, 15, 1456; (b) S. V. Ley, Chem. Rec., 2012, 12, 378-390; (c) J.-i. Yoshida, H. Kim and A. Nagaki, ChemSusChem, 2011, 4, 331.

11. M. Meldal and C. W. Tornøe, Chem. Rev., 2008, 108, 2952.

12. S. Bräse, C. Gil, K. Knepper and V. Zimmermann, Angew. Chem. Int. Ed., 2005, 44, 5188.

13. (a) N. Kockmann, M. Gottsponer and D. M. Roberge, Chemical Engineering Journal, 2011, 167, 718; (b) C. J. Smith, N. Nikbin, S. V. Ley, H. Lange and I. R. Baxendale, Org. Biomol. Chem., 2011, 9, 1938; (c) P. J. Nieuwland, R. Segers, K. Koch, J. C. M. van Hest and F. P. J. T. Rutjes, Org. Process Res. Dev., 2011, 15, 783.

14. (a) B. H. Lipshutz and B. R. Taft, Angew. Chem.Int. Ed., 2006, 45, 8235; (b) M. Fuchs, W. Goessler, C. Pilger and C. O. Kappe, Adv. Synth. Catal., 2010, 352, 323.

15. (a) C. Girard, E. Önen, M. Aufort, S. Beauvière, E. Samson and J. Herscovici, Org. Lett., 2006, 8, 1689; (b) C. D. Smith, I. R. Baxendale, S. Lanners, J. J. Hayward, S. C. Smith and S. V. Ley, Org. Biomol. Chem., 2007, 5, 1559; (c) E. Ozkal, S. Ozcubukcu, C. Jimeno and M. A. Pericas, Catal. Sci. Technol., 2012, 2, 195.

16. (a) S. B. Ötvös, I. M. Mándity, L. Kiss and F. Fülöp, Chem. Asian J., 2013, 8, 800; (b) S. B. Ötvös, Á. Georgiádes, I. M. Mándity, L. Kiss and F. Fülöp, Beilstein J. Org. Chem., 2013, 9, 1508.

17. (a) A. R. Bogdan and N. W. Sach, Adv. Synth. Catal., 2009, 351, 849; (b) A. R. Bogdan and K. James, Chem. European J., 2010, 16, 14506; (c) S. Ceylan, T. Klande, C. Vogt, C. Friese and A. Kirschning, Synlett, 2010, 2009.; (d) A. R. Bogdan and K. James, Org. Lett., 2011, 13, 4060.

18. A. C. Varas, T. Noël, Q. Wang and V. Hessel, ChemSusChem, 2012, 5, 1703.

19. (a) S. Kovacs and Z. Novak, Org. Biomol. Chem., 2011, 9, 711; (b) S. Kovács, K. Zih-Perényi, Á. Révész and Z. Novák, Synthesis, 2012, 44, 3722; (c) A. Székely, Á. Sinai, E. Tóth, Z. Novák, Synthesis 2014, 46, 1871.

20. Z. Gonda and Z. Novak, Dalton Trans., 2010, 39, 726.

21. R. Hudson, C.-J. Li and A. Moores, Green Chem., 2012, 14, 622.

22. (a) V. O. Rodionov, V. V. Fokin and M. G. Finn, Angew. Chem. Int. Ed., 2005, 44, 2210; (b) C. Shao, X. Wang, Q. Zhang, S. Luo, J. Zhao and Y. Hu, J. Org. Chem. 2011, 76, 6832.

23. (a) C. Nolte, P. Mayer and B. F. Straub, Angew. Chem. Int. Ed., 2007, 46, 2101; (b) C. Shao, G. Cheng, D. Su, J. Xu, X. Wang and Y. Hu, Adv. Synth. Catal., 2010, 352, 1587; (c) C. Shao, X. Wang, J. Xu, J. Zhao, Q. Zhang and Y. Hu, J. Org. Chem., 2010, 75, 7002.

24. N. Tu, J. Hochlowski and S. Djuric, Mol. Divers., 2012, 16, 53.

25. V. Ganesh, V. S. Sudhir, T. Kundu and S. Chandrasekaran, Chem. Asian J., 2011, 6, 2670.

26. (a) B. H. M. Kuijpers, G. C. T. Dijkmans, S. Groothuys, P. J. L. M. Quaedflieg, R. H. Blaauw, F. L. van Delft and F. P. J. T. Rutjes, Synlett, 2005, 3059; (b) J. E. Hein, J. C. Tripp, L. B. Krasnova, K. B. Sharpless and V. V. Fokin, Angew. Chem. Int. Ed., 2009, 48, 8018; (c) J. Garcia-Alvarez, J. Diez and J. Gimeno, Green Chem., 2010, 12, 2127; (d) M. Juríček, K. Stout, P. H. J. Kouwer and A. E. Rowan, Org. Lett., 2011, 13, 3494.

27. (a) S. Díez-González, A. Correa, L. Cavallo and S. P. Nolan, Chem. Eur. J., 2006, 12, 7558; (b) R. K. Arigela, A. K. Mandadapu, S. K. Sharma, B. Kumar and B. Kundu, Org. Lett., 2012, 14, 1804.

28. R. Berg and B. F. Straub, Beilstein J. Org. Chem., 2013, 9, 2715.

29. P. Shanmugavelan, S. Nagarajan, M. Sathishkumar, A. Ponnuswamy, P. Yogeeswari and D. Sriram, Bioorg. Med. Chem. Lett., 2011, 21, 7273. 